\title{
ДО ПИТАННЯ ЛЕКСИЧНОГО ТА СЕМАНТИЧНОГО КАЛЬКУВАННЯ В ПУБЛІЦИСТИЦІ М. ГРУШЕВСЬКОГО
}

Клімчук Г.П. До питання лексичного та семантичного калькування в публіцистиці М. Грушевського.

У статті досліджено механізм словотвірного й семантичного калькування німецьких та польських лексичних засобів на матеріалі публіцистичного доробку М. Грушевського. Здійснено аналіз структурних особливостей, семантичного складу й функціональних можливостей кальок із німецької й польської мов у західноукраїнській мовно-літературній традиції кінця XIX - початку XX ст.; з'ясовано стилістичний статус окреслених лінгвоодиниць у сучасному літературному вжитку.

Ключові слова: запозичення, калькування, лексичні (словотвірні) та семантичні кальки, полонізми, германізми, західноукраїнська мовно-літературна традиція.

Климчук Г.П. К вопросу лексического и семантического калькирования в публицистике М. Грушевского.

В статье исследуется механизм словообразовательного и семантического калькирования немецких и польских лексических средств на материале публицистики М. Грушевского. Осуществлен анализ структурных особенностей, семантического состава и функциональных возможностей калек с немецкого и польского языков в западно-украинской традиции литературного языка конца XIX - начала XX вв.; определен стилистический статус соответственных языковых единиц в современном литературном употреблении.

Ключевые слова: заимствование, калькирование, лексические (словообразовательные) и семантические кальки, полонизмы, германизмы, западноукраинская традиция литературного языка. 
Klimchuk G. P. To the question of lexical and semantic replication in publicism of M. Grushevskii.

The article deals with the formative mechanism and semantic replication German and Polish lexical means on the material of publicism of M. Grushevskii. The author has made an analysis of the structural features, semantic structure and functional capabilities of the replications from German and Polish in the western Ukrainian tradition of literary language in the late 19th - early 20th century; determined the status of the stylistic language units in modern literary usage.

Key words: borrowing, replication, lexical and semantic replication, polonisms, germanisms, the western Ukrainian tradition of literary language.

У сучасній українській лінгвістичній царині дедалі посилюється загальне зацікавлення вивченням проблем історії літературної мови. Особливої актуальності в цьому аспекті набувають дослідження питань функціонування й соціальної репрезентації української мови в один із найбільш продуктивних відтинків эï розвитку - кінець XIX та початок XX ст. - період, коли лексичний склад української мови переживав справжню революцію. Літературні контакти, узаємодія споріднених літературних мов у час національного ренесансу значно збагатили словник української мови.

Висока відтворюваність чужоземних запозичень в українському слововжитку кінця XIX - початку XX ст. була не лише наслідком міжмовної інтерференції, спричиненої впливом на українську мову в результаті безпосереднього контактування територіально суміжних мов країн-завойовників, але й зумовлювалася дією суто лінгвістичних чинників, зокрема потребою залучення нових виражальних засобів для номінації абстрактних понять із царини матеріального та інтелектуального життя, яких, через відсутність державності й недостатню сформованість вищих функціональних стилів, українській мові вкрай бракувало. 3 огляду на це проникнення окремих елементів норм німецької, польської, російської й інших мовних систем в українську було «природно неминучим, оскільки вони (мови - Г. К.) мали за собою тривалу традицію офіційно-адміністративного вживання і виступали провідниками-посередниками в засвоєнні українською мовою нових реалій і понять, пов'язаних із культурними здобутками сусідніх народів» [13, с. 88]. Подолання дефіциту власних номінативних засобів іншомовними лексичними надходженнями в цей час реалізовувалося передусім потугами національно свідомої української інтелігенції, представники якої намагалися інтелектуалізувати рідну мову, піднести їі до рівня стилістично виповнених західноєвропейських. Помітну роль у 
когорті окреслених громадсько-культурних діячів відіграла мовна особистість М. Грушевського, значення якого в історії мови й досі залишається вкрай маловивченим та не завжди об' єктивно оціненим.

Одним із специфічних різновидів західноєвропейського впливу на українську мову кінця XIX - початку XX ст., що виразно простежується на матеріалі публіцистичної спадщини М. Грушевського, є калькування. Відтак мета нашої статті полягає в тому, аби вивчити механізм словотвірного та семантичного калькування лексичних елементів німецького й польського походження в політичному дискурсі М. Грушевського. Для реалізації поставленої мети передбачаємо розв'язання таких завдань: 1) виявити в аналізованому мовному матеріалі лексеми та лексико-семантичні варіанти, що постали в результаті калькування німецьких чи польських прототипів; визначити їх функції; 2) з'ясувати стилістичний статус зафіксованих лінгвоодиниць у сучасній українській мові (за матеріалами «Словника української мови» в 11-ти томах).

Спостереження за лексичною організацією публіцистичної спадщини М. Грушевського демонструє активну апеляцію автора до чужоземного джерела. Серед значного масиву західноєвропейських запозичень, засвідчених досліджуваним матеріалом, помітне місце посідають германізми й полонізми. Принагідно зазначимо, що в україністиці окресленими мовними засобами кваліфікують не тільки слова, але й окремі значення, вислови і т. ін., запозичені відповідно 3 німецької чи польської мов або утворені за їх зразком. Тому у пропонованій науковій розвідці цілком закономірним уважаємо номінування термінами «германізми» та «полонізми» лексем чи лексико-семантичних варіантів, що постали внаслідок структурного / семантичного копіювання німецьких або польських еквівалентів.

Варто зауважити, що питання розмежування власне запозичень і кальок у сучасній лінгвістичній практиці належно не опрацьоване. Причина цього, як припускає Г. Бідер, полягає в тому, що розробка відповідної проблеми вимагає грунтовної компетенції дослідника в лексичних системах різних мов: часто нерозпізнання чужоземних прототипів багатьох українських новотворів кінця XIX - початку $\mathrm{XX}$ ст. «створює помилкове враження, ніби всі терміни є оригінальні формації, придумані західноукраїнськими граматиками, але насправді майже всі такі терміни постали внаслідок структурного копіювання 
іноземних відповідників» [3, с. 87]. Дослідники послідовно розрізняють два різновиди калькування - лексичне та семантичне.

Під лексичним (або словотвірним) калькуванням у науковій літературі розглядають процес творення нових слів шляхом позичання лексико-семантичних моделей іншої мови та заповнення їх морфемами власної мови [2, с. 188]. Відтак лексичними, або словотвірними, кальками кваліфікуємо лексеми, що виникли на українському грунті в результаті буквального поморфемного перекладу чужомовних відповідників. У дописах М. Грушевського зазначена категорія кальок репрезентована передусім германізмами.

За нашими спостереженнями, переважна більшість словотвірних кальок німецької етимології в аналізованих публікаціях представлена суспільно-політичними терміноодиницями, що активно функціонували в галицькому комунікативному просторі кінця XIX - початку XX ст., однак на сьогодні відійшли до пасивного словника української мови, наприклад: відпоручник Ł нім. der Sendbote (senden «відправляти, відсилати» + der Bote «посланець, кур'єр; розсильний») - «представник, посильний, уповноважений»: Більш як чотириста селян приїхало з ріжних кутів Галичини як вибрані повітовими зборами відпоручники [7, с. 47]; nociлicmь $\leftarrow$ нім. der Besitz, das Besitzen (be «невідокремлюваний німецький дієслівний префікс, що означає доконаність, завершення дії» + setzen «сідати») - «володіння, власність»: B сім краю руська організаційна робота оперує головно тільки селянством і священством, бо більша посілість («крупная поземельная собственность») в руках поляків і жидів... [5, с. 141]; правосильність $\leftarrow$ нім. Rechtkraft (Recht «право» + Kraft «сила») - «правомочність»: ....зборам грозить дуже мала чисельність, а щз для правосильності зборів треба тільки 50-х членів, то Виділ і прибрані ним почесні члени мають можність великої переваги a priori [7, с. 84]; міродайний $\longleftarrow$ нім. massgebend (das Maß «міра» + geben «давати») - «авторитетний, компетентний, впливовий»: ...pусини звертали увагу в міродайних сферах на потребу утраквізаиії його (виділу - Г. К.) і вказували на численних кандидатів-русинів у Австрії і на російській Украӥні... [5, с. 176].

На німецьку етимологію номена відпоруцник указує І. Огієнко (пор.: відпоручник - «часто вживане в Галичині слово, виковане 3 німецької, на Великій Україні - представник, заступник, післанец̧ь» $[10$, с. 65]). «Словник української мови» (далі - СУМ) уносить до реєстрової частини відповідний термін, проте знижує його стильовий 
потенціал обмежувальною позначкою діалектне (пор.: відпоручник, діал. - уповноважений [12, I, с. 622]), натомість у «Великому тлумачному словнику сучасної української мови» (далі - ВТССУМ) фіксуємо переорієнтацію маркування цієї лексеми на західну (пор.: відпоручник, заx. - уповноважений, представник [4, с. 136]).

Наявність подібного до посілість абстрактного утворення в польській мові (пор.: пол. posiadtość - володіння, власність; нерухомість; помістя), очевидно, свідчить по посередництво останньої в перейманні аналізованої терміноодиниці українським узусом. У СУМ субстантив посілість трактується як рідковживаний i застарілий (пор.: посілість, заст., рідко - володіння, маєток) [12, VII, с. 329]).

Юридичний термін правосильність не реєструється сучасною лексикографічною практикою, водночас представленість його в «Малорусько-німецькому словарі» (далі - МНС) (пор.: правосильність Rechtkraft; правосильний - rechtskräftig [9, II, с. 733]) указує на поширеність цього іменника в галицькому мовленнєвому середовищі кінця XIX ст. Можна припустити, що продукування зазначеного терміна в західноукраїнському слововжитку було пов'язане 3 опозитивними тенденціями щодо польської та російської мов, де для номінації окресленого поняття використовувалися тотожні лексичні засоби (пор.: рос. правомочность, пол. prawomocność), що, вірогідно, теж постали через словотвірне копіювання того ж таки німецького композита Rechtkraft, у якому друга складова $є$ багатозначною (пор.: нім. die Kraft - 1) сила, міць, фіз. енергія; 2) робітник).

Прикметник міродайний не відображений сучасними академічними словниками (СУМ, ВТССУМ), однак його вміщує «Український стилістичний словник» (далі - УСС) І. Огієнка, що характеризує аналізовану лексему як «кострубатий новотвір недавнього часу», часто відтворюваний на теренах Галичини «невдалий переклад нім. massgebend»; замість нього автор пропонує використовувати відомі на Наддніпрянщині слова керуючий і провідний [10, с. 230].

М. Грушевського також цілком справедливо можна вважати провідником у загальноукраїнську мовно-літературну традицію сконструйованої на галицькому грунті словотвірної кальки niдприсмство, що походить із нім. Unternehmen $(\leftarrow$ unter «під» + nehmen «приймати») і нині стала надбанням українського узусу, напр.: Професори-поляки не старалися перейти російських в заповнюванні російських видавниџтв своїми прачями, не старалися блиснути на (ㄷ Г. П. Клімчук, 2012. 
загальноросійських з'їздах, а віддавали свою пращю місцевим польським культурним $і$ науковим підприемствам... [6, с. 79]. СУМ фіксує лексему підприсмство без будь-яких обмежувальних ремарок (пор.: підприємство - 1) окрема виробнича установа (завод, фабрика); 2) діяльність у якій-небудь галузі, що дає прибутки [12, VI, с. 487]), проте на початку XX ст. літературна придатність та функціональностилістичний потенціал цього новотвору були предметом гострих науково-публіцистичних суперечок й піддавалися різкій критиці 3 боку представників східноукраїнської інтелігенції. Так, скажімо, попри наявність зазначеного іменника в МНС (пор.: підприсмство Unternehmung [9, II, с. 648]), «Словарь української мови» не вносить його до реєстрової частини, а I. Нечуй-Левицький у розвідці «Криве дзеркало української мови», аналізуючи мовний склад публікації М. Грушевського «На Україні» (за 1910 рік), зараховує субстантив підприємство до переліку так званих «хиб» галицької книжної мови $і$ пропонує замінити відповідником запопа́дність. На подібну оцінку лінгвоодиниці підприємство натрапляємо й у виданому 1923 року УСС, автор якого наголошує, що підприємство - це «переклад $n$. przedsiębierstwo; треба - торгівля, заняття, фабрика, гандель (курсив наш - Г. К.)» [10, с. 283]. Зауважимо, що аргументація I. Огієнка стосовно польської етимології слова підприємство, на наш погляд, недостатньо науково обгрунтована, адже за умови структурного копіювання пол. przedsiebierstwo на українському грунті мав би постати дериват на кшталт «під-себе-ство» (у буквальному перекладі пол. siębie = укр. ceбe). Тому ми обстоюємо думку, згідно 3 якою лексичний елемент підприємство - це вірогідніше за все калька німецького Unternehmen «підприємство; справа», пов'язаного 3 дієсловом unternehmen «розпочати, взятися», що складається 3 префікса unter «під» і дієслова nehmen «брати, приймати».

Як доводить проілюстрований матеріал, лексичні кальки 3 німецької мови не завжди максимально точно й «фотографічно» відтворюють морфемний склад німецьких еквівалентів, подекуди вони лише приблизно імітують їх словотвірну структуру. Це демонструє творчий характер мови-рецептора, позаяк скальковане за чужоземним зразком слово «так чи інакше зорієнтоване на фонетикофонологічні, морфемні, словотворчі, граматичні та семантичні потреби і можливості тієї мови, у якій воно створюється» [1, с. 13], а також виступає переконливим доказом того, що скопійована 3 
німецьких відповідників українська суспільно-політична термінологія створювалася не лише на основі досягнень міжнародної практики термінотворення, але й з урахуванням національних традицій.

Крім лексичного, у публіцистичному доробку М. Грушевського виявляємо випадки семантичного калькування німецьких та польських відповідників, коли під впливом мови-моделі слово мови-реципієнта починає розширювати своє значення. Суть семантичних кальок зводиться до того, що вони «проникають у лексико-семантичну структуру питомого слова тієї мови, яка засвоює (запозичує) значення чужомовного слова на асоціативній основі прямого денотативного значення слів-корелятів мов взаємного контактування» [13, с. 88]. Іншими словами, цей різновид калькування загалом виникає тоді, коли зв'язки між суміжними (контактуючими) лінгвоспільнотами настільки стійкі, що мовці починають автоматично переносити семантичні відтінки, притаманні чужомовним лексемам, на ідентичні одиниці рідної мови. Розпізнавальним тлом семантичних кальок $є$ насамперед залучення широкого контексту.

Більшість зафіксованих нами в публіцистиці М. Грушевського семантичних кальок із німецької мови (або семантичних германізмів) виступають репрезентантами західноукраїнського зразка літературної мови досліджуваного періоду. Вони представлені передусім граматичним класом дієслів, зрідка іменниками, що обслуговували на зламі XIX i XX ст. сферу офіційно-ділового адміністрування й соціально-політичних відносин у суспільстві, наприклад: заіменовано - «призначено на посаду»; іменуватися - «призначатися»; «присуджувати чин»; іменування «призначення на посаду»; «присудження звання»: Заразом виринули ще дві кандидатури василіан на єпископські катедри - сього ж о. Філяса на львівського вікарія, 〈..> а згаданого гр[афа] Шептищького на Станіславську єпархію. Шептищького дійсно вже заіменовано, іменуванню вікарія спротивився митр[ополит] Куйловський, а як буде з іменуванням о. Філяса ректором, іме не знати [5, с. 148]; ...nосли будуть не вибиратися, а іменуватися - чи крайовим правительством, чи крайовими партійними організачіями, зовсім незалежно від замірів $i$ планів місчевої людності... [6, с. 319]; Після того, в квітні 1894 р., мене заіменовано звичайним професором до Львова [5, с. 119] (пор.: нім. benennen - 1) називати, іменувати; 2) висувати (кандидатуру); ernennen призначати; nennen «називати; звати; давати ім'я»; пол. mianować na stanowisko - призначити на посаду); обсадити (иколи) - «укомплектувати (призначити) вчительський склад»; обсадження (університету) - 
«укомплектування професорсько-викладацького складу університету»; обсаджена (кафедра) - «призначено завідувача кафедри»: ...3 браку кваліфікованих кандидатів русинів «прийдеться» раді шкільній $z$ konieczności обсаджувати ӥх (школи - Г. К.) поляками та полькали, зовсім не обізнаними з руською мовою [5, с. 275]; П'ятнадиять чи навіть десять літ тому назад могли бути сумніви щзодо дозрілості сеї справи, щэодо можності обсадження українськими силами цүілого університету [7, с. 80]; Коли умер Ол. Огоновський, його катедра протягом вісьмох літ зіставалася не обсадженою [5, с. 180] (пор.: нім. einsetzen - 1) вставляти; поміщати; вправляти; вшивати; 2) призначати на посаду (ким); укомплектовувати; 3) вводити в дію; 4) військ. уводити в бій; 5) саджати (рослини); setzen - 1) поставити; покласти; посадити; 2) установити; призначити; пол. obsadzić - 1) обсадити (чимось); 2) зайняти посаду, 3) призначити на посаду, укомплектувати штати); тіло (професорське), перен. - «професорський колектив (об'єднання)»; тіло (державне), перен. - «державний організм (корпус)»: Розуміється, для сього розрубання потрібне сильне напруження всіх політичних чинників $i$ засобів; українська академічна молодіж, тим менше - українське тіло професорське сього не осягнуть [7, с. 81]; А на полудні плани сербськочорногорського митового союзу, <...> і об'єднання в одне державне тіло Сербї $і$ Чорногорії - перспективи одна гірше другої для Австрії [6, с. 472] (пор.: нім. der Körper - 1) тіло, тулуб, корпус; 2) організм; die Körperschaft колектив, об'єднання, орган, установа; пол. ciato, перен. - колектив, склад).

Наведені приклади демонструють, що калькування значень німецьких лінгвоодиниць зумовлювалося буквальним сприйняттям мовцями семантики їх кореневих морфем, унаслідок чого на автохтонну українську лексему накладалися значення співвідносного 3 нею слова контактуючої (німецької) мови. Представленість подібних семантичних кальок у польському узусі, очевидно, указує на польське посередництво в перейманні відповідних сем українською мовою.

Польська мова була не лише посередницею в позичанні українською окремих значень німецьких лексем, нерідко польські лексичні засоби також ставали об'єктом семантичного калькування. Так, публіцистична практика М. Грушевського виявляє численні приклади запозичення окремих лексико-семантичних варіантів польських слів, поява яких була наслідком семантичної інтерференції, спричиненої впливом на українську мову близькоспорідненої польської. Зауважимо, що семантичною інтерференцією учені 
називають розширення значення слова мови-рецептора за зразком співвідносного корелята мови-моделі [8, с. 122], тому під семантичними полонізмами у пропонованому дослідженні розглядаємо окремі (часто переносні) значення в семантичній структурі лексем української мови, що постали за аналогією до польських відповідників - як семантичні кальки 3 польської мови.

В аналізованому мовному матеріалі випадки семантичного копіювання польських прототипів насамперед спостерігаємо в лінгвоодиницях слов'янського лексичного фонду, адже, як відомо, інтерференція найчастіше відбувається в генетично близьких мовах, коли схожість матеріальної оболонки етимологічно споріднених слів зумовлює «вирівнювання» їх планів змісту. Репрезентантами цього різновиду семантичних полонізмів здебільшого виступають віддієслівні іменники, напр.: виклад - «лекція»: Вибрано Костомарова професором в Петербурзькім університеті, сила людей ходила на його виклади [7, с. 307] (пор.: пол. wyktad - лекція; виклад - 1) письмова чи усна розповідь, опис, передача яких-небудь фактів, матеріалів і т. ін.; 2) стиль, манера розповіді, опису; 3) діал. лекція [12, I, с. 406]); знесення - «скасування (смертної кари; заборони)»: Дума переводить дискусію над знесенням кари смерті... [5, с. 357]; Галицька Украӥна разом з російською з напруженням чекала початків конституиійної ери і разом з нею - знесення заборони украӥнського слова... [6, с. 328] (пор.: пол. znieść - 1) знести; 2) скасувати; zniesienie - скасування, відміна); роздряпання, перен. - «розтягнення, роз'єднання»: Албанське питання стало новою точкою приложення для всяких політичних комбінацій, обрахованих на роздряпання нової Туреччини, яка показала себе зовсім не сильнішою, не більше об'єднаною, ніж стара деспотія Абдул-Гаміда [7, с. 448] (пор.: пол. rozdrapywać - 1) роздряпувати; 2) перен. роз'єднати, розтягати); опусm - «знижка, уцінка»: Видання випускалися дорого, давалися комісіонерам з великим опустом... [6, с. 108] (пор.: пол. орust - знижка; оnycm, діал. - шлюз [12, V, с. 735]; опусm - 1) діал. шлюз; 2) зах. здешевлення товару [4, с. 678]).

Частотними в мовній практиці М. Грушевського є також приклади появи нових лексико-семантичних варіантів у субстантивах неслов' янського (передусім грецького та латинського) походження, що належать до спільного для української й польської мов інтернаціонального фонду лексики, наприклад: академія - «урочисті збори»: Відчит проф. Грушевського на науковій академії, 
спорядженій дня 1 падолиста 1898 р. на пам'ятку столітніх роковин відродження украӥнсько-російської літератури [5, с. 111] (пор.: пол. akademia - 1) академія (instytucja); 2) урочисті збори (impreza); академія - «так в Г. $3 n$. називають святкування якогось письменника, чи взагалі свято $з$ лекцією на культурно-освітню тему; на В. У. літературний вечір чи ранок, присвячений комусь» [10, с. 14]; суч. укр. академія ( $\leftarrow$ лат. Academia $\leftarrow$ грец. Akadēmeia) -1$)$ філософська школа, заснована Платоном близько 387 р. до н. е.; 2) вищий науковий заклад; 3) назва багатьох наукових установ, товариств і навчальних закладів; 4) тип музичної інституції, що організовує публічні концерти та здійснює постановки опер [11, с. 39]); інавгурація «урочисте відкриття виставки»: Крім місцевих виборів, мала відбутися вистава господарської худоби дня 20; я не бачив ї̈, <...> усунення місиевих русинів відбирало у мене охоту брати участь в офіціальній ї̈ інавгурації [5, с. 245] (пор.: пол. inauguracja 1) урочисте відкриття (сезону, навчального року); 2) заст. урочистий вступ на посаду; суч. укр. інавгурація ( $\leftarrow$ лат. inaugurare посвячувати) - урочиста церемонія введення на посаду глави держави або посвячення в сан [11, с. 463]); меморіал - «доповідна записка»: Особливо Наукове товариство ім. Шевченка в своїм останнім меморіалі дуже сильно вказувало на необчислимі шкоди, які терпить від сього не тільки наше наукове життя, але й культурні інтереси всеї Галицької Русі, всього краю [7, с. 39] (пор.: пол. memorial доповідна записка; суч. укр. меморіал ( $\leftarrow$ лат. memorialis - пам’ ятний < mётегria - пам'ять) - 1) apxim. скульптурний комплекс, що увічнює пам'ять про кого-, що-небудь; 2) спортивні змагання, присвячені пам'яті видатних спортсменів [11, с. 630]).

Аналіз змісту продемонстрованих мовленнєвих ситуацій свідчить, що семантичні полонізми в політичній спадщині М. Грушевського переважно обслуговували офіційно-ділову й культурно-інтелектуальну царини суспільного життя та виступали своєрідним «номінативним мінімумом» для відображення нових явищ позамовної дійсності. У сучасній мовно-літературній традиції відповідні значення занепали: вони або взагалі не відтворюються СУМ, або ж супроводжуються ремарками застаріле, розмовне чи діалектне, що не завжди об'єктивно віддзеркалює їх стилістичний потенціал у мовленні української інтелігенції на зламі XIX і XX ст. 
Отже, у публіцистичній спадщині М. Грушевського представлений помітний пласт мовних одиниць, утворених унаслідок лексичного чи семантичного калькування німецьких або польських прототипів. СУМ не відображає в повному обсязі соціальної специфіки й семантико-стилістичних характеристик зафіксованих мовних засобів: вони або взагалі не внесені до реєстру, або їх семантична структура відбита лише частково - не враховано західноукраїнські лексико-семантичні варіанти, або ж без належної об'єктивної мотивації знижено стилістичний статус лексем. 3 цієї причини чимало аналізованих германізмів і полонізмів опинилося за межами або на периферії словникового складу сучасної української літературної мови. Можна припустити, що деякі з них продовжують функціонувати в мовленнєвому середовищі української діаспори чи окремих галицько-буковинських говірках, де зберігають притаманне їм на початку XX ст. стилістичне забарвлення, однак відповідна лінгвістична проблема потребує спеціального дослідження.

\section{Література}

1. Акуленко В. В. Німецький вплив на розвиток української мови : Проблеми методології / В. В. Акуленко // Мовознавство. - 1997. - № 1. - С. 12-18.

2. Ахманова О.С. Словарь лингвистических терминов / Ольга Сергеевна Ахманова. - М. : Советская энциклопедия, 1966. - 608 с.

3. Бідер Г. Про мовознавчу термінологію Івана Франка : Аспекти наукових i мовних контактів / Герман Бідер // Ucrainistica : зб. наук. праць. - Кривий Ріг. - 2007. C. 80-89.

4. Великий тлумачний словник сучасної української мови / [уклад. і гол. ред. В. Т. Бусел]. - К. ; Ірпінь : ВТФ «Перун», 2003. - 1440 с.

5. Грушевський М. Твори : у 50 т. / Михайло Грушевський / ред. : П. Сохань (голов. ред.) та ін. - Л. : Світ, 2002. - Т. 1 : Серія «Суспільно-політичні твори (18941907)». $-592 \mathrm{c.}$

6. Грушевський М. Твори : у 50-и т. / Михайло Грушевський / ред. : П. Сохань (голов. ред.) та ін. - Л. : Світ, 2005. - Т. 2 : Серія «Суспільно-політичні твори (1907914)». $-704 \mathrm{c}$.

7. Грушевський М. Твори : у 50-и т. / Михайло Грушевський / ред. : П. Сохань (голов. ред.) та ін. - Л. : Світ, 2005. - Т. 3 : Серія «Суспільно-політичні твори (1907 березень 1917)». - $792 \mathrm{c}$.

8. Жлуктенко Ю. О. Мовні контакти : Проблеми інтерлінгвістики / Юрій Олексійович Жлуктенко. - К. : Вид-во Київ-го ун-ту, 1966. - 135 с.

9. Малорусько-німецький словар : у 2-х т. / [авт.-уклад. Є. Желехівський, С. Недільський]. - Львів, 1886. - Т. І. - 589 с. ; Т. ІІ. - 1117 с.

10. Огієнко І. Український стилістичний словник : Підручна книжка для вивчення української літературної мови / Іван Огієнко. - [2-е вид.]. - Вінніпег ; Канада, 1978. - 477 с.

11. Словник іншомовних слів / [Пустовіт Л. О., Скопенко О. І., Сюта Г. М. та ін.] ; ๑) Г. П. Клімчук, 2012. 
за ред. Л. О. Пустовіт. - К. : Довіра, 2000. - 1017 с.

12. Словник української мови : в 11 т. - К. : Наукова думка, 1970. - Т. І. - 799 с. ; 1974. - T. V. - 840 c. ; 1975. - T. VI. - 832 c. ; 1976. - T. VII. - 723 c.

13. Ткач Л. О. Німецькі запозичення в українській літературній мові Буковини кінця XIX - початку XX ст. (дієслівні семантичні кальки) / Л. О. Ткач // Науковий вісник Чернівецького університету : зб. наук. праць. - Вип. 84 : Германська філологія. Чернівці : Рута, 2000. - С. 84-95.

Стаття надійшла до редакції 31.10.2012 p. 